\title{
THE INFLUENCE OF AERATION RATIO ON ENERGETIC ASPECTS OF COMPOSTING PROCESS OF SEWAGE SLUDGE WITH AGRICULTURAL WASTE
}

\author{
Jakub MAZURKIEWICZ1 ${ }^{1}$, Magdalena MYSZURA ${ }^{2}$, Kamil KOZLOWSKI ${ }^{1}$, \\ Anna SMURZYŃSKA ${ }^{1}$, Sebastian KUJAWIAK ${ }^{1}$ \\ ${ }^{1}$ Poznan University of Life Sciences, POLAND \\ ${ }^{2}$ University of Life Sciences in Lublin, POLAND \\ E-mail of corresponding author: jakub.mazurkiewicz@up.poznan.pl
}

Keywords: wastewater sludge, sewage sludge, composting, aeration, agricultural waste

\begin{abstract}
Composting process of sewage sludge is one of the most common methods in the world for sludge management. Due to, inter alia, unfavorable ratio of carbon to nitrogen and the high hydration, sludge waste requires usually additional preparation before composting process. Especially in agricultural areas, the use of agricultural waste seems to be beneficial to improve the properties of the compost mixture. Such co-substrates will create favorable water and air conditions inside the pile or in-vessel. In addition to the composition of the mixture, another important aspect is the appropriate aerating of the compost. It depends on what time and how effective will be the composting process. The aim of the work was to present the influence of aeration ratio on energetic aspects of composting process of sewage sludge with agricultural biomass. In this case maize straw was the structural addition.
\end{abstract}

\section{COMPOSTING OF SEWAGE SLUDGE WITH AGRICULTURAL WASTE}

Reducing the number of livestock farming has contributed to the decline in the production of natural fertilizers, which resulted in the search for alternative, environmentally safe sources of organic matter, which can be composted sludge, processed into fertilizer in agriculture (Szwedziak 2006).

Wastewater sludge is a significant biomass resource in the scale of the economy, which can be used in various ways. Analysis of Eurostat data shows that Poland is at the top of the sewage sludge production (above 568000 tons/year, data from 2015 data) only from the urban wastewater treatment process (Eurostat 2017). Large volumes of such waste are only produced by Germany, United Kingdom, France Spain and Italy - it is estimated that these five countries generate altogether almost $75 \%$ of the European wastewater sludge (Kacprzak 2017).

Analyzing the directions of wastewater sludge management in Europe and Poland in the recent years, there is a strong trend towards reducing the amount of sediment deposited on landfills in favor of their agricultural use and composting (Duan 2017, Eurostat 2017).

Properly managed composting process is one of the most common waste management methods, as far as sustainability issues are concerned to stabilize organic waste including wastewater sludge results in stable and harmless end-product, which may be used as a fertilizer or soil conditioner that does not pose an environmental hazard (Białobrzewski et al. 2015, Kosicka 2015 et al., Malamis et al. 2016). Composting is a viable, beneficial option in biosolids management and it is a proven method for pathogen reduction and results in a product that is easy to handle, store, and use (BauzaKaszewska 2010 et al., Starzyk and Czekała 2014, Mroczek-Krzyzelewska et al. 2017).

Wastewater sludge composting technology is typically done at higher temperatures (Berggren 2004) which imitates an accelerated natural process that takes place on open 
floor where the organic materials (leaf litter, animal wastes) are broken down. Resulting in an overall reduction of volume, or converted to more stable organic materials.

\section{CHARACTERISTICS OF WASTEWATER SLUDGE}

The composition of sewage sludge depends on the organic and mineral content of the wastewater and the degree of mineralization of the organic substance in the stabilization processes. Dewatered wastewater sludge (dry), depending on stabilization processes, contains on average $50-70 \%$ of organic matter, and $30-50 \%$ mineral components (including 1-4\% of inorganic carbon), 3.4-4.0\% N, 0.5-2.5\% $\mathrm{P}$ and significant amounts of other nutrients, including micronutrients (Kacprzak 2017, Kosicka 2016 et al.).

Due to inter alia unfavorable ratio of carbon to nitrogen and the high hydration, sludge waste requires usually additional preparation before composting process (Czekała et al. $2015,2016)$. For these reasons, the use of wastewater sludge as an unconventional fertilizer contributes, according to Jezierska-Tyś et al. (2004) to improve the physicochemical properties of the soil, have a soil-forming effect, and also promote the accumulation of humus compounds.

Especially in agricultural areas, the use of agricultural waste seems to be beneficial to improve the properties of the compost mixture (Ucaroglu and Alkan 2016, Grau et al. 2017). Such co-substrates will create favorable water and air conditions inside the pile or in-vessel. In addition to the composition of the mixture, another important aspect is the appropriate aerating of the compost.

\section{METHODOLOGY, SCOPE AND OBJECT OF RESEARCH}

The research was carried out at the Institute of Biosystems Engineering at the Poznan University of Life Sciences, in the Laboratory of Environmental Technology. The composting process was carried out in specially designed bioreactors (Fig. 1). The influence of external factors was eliminated by the use of thermal insulation.

In order to ensure adequate structural properties of the composted feed, the ingredients were selected in appropriate proportions. The sewage sludge from the municipal wastewater treatment plant and the agricultural waste in the form of straw rape were used for the study. The dry weight was $18.61 \%$ for sludge and, for rapeseed straw, $87.71 \%$. In the experiment $25 \mathrm{~kg}$ of sludge and $5.4 \mathrm{~kg}$ of rape straw were used in each compartment.

Seven models of bioreactors were used for testing. Each of them was built in the shape of a cuboid with a side length of $0.5 \mathrm{~m}$, height of $0.7 \mathrm{~m}$ and has a capacity of $165 \mathrm{dm} 3$. The walls of the chambers are made of plastic and additionally reinforced by metal elements. The walls of the chambers were insulated thermally.

Aeration of the bioreactors was carried out using an air-pumping pump (Fig. 1, item 1). The amount of air injected into the chambers was controlled and evenly distribution of the pressurized air allowed the metal grate, at the bottom of the tank. 


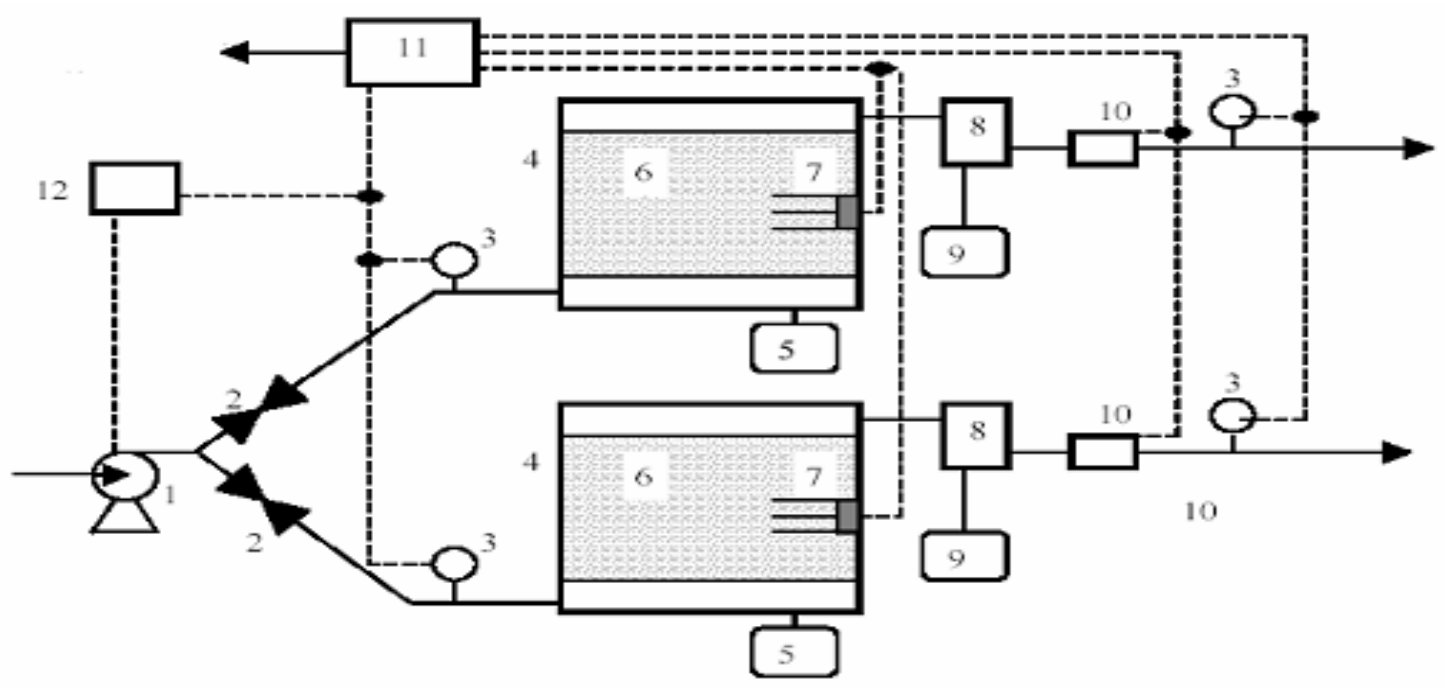

Figure 1. Diagram of 2-chamber bioreactor section (1. pump, 2. air flow regulator, 3. flow meter, 4. chamber, 5. leach tank, 6. composted mixture, 7. measuring sensor assembly, 8. air cooling system, 9. condensate tank, 10. gas sensors ( $\mathrm{NH} 3, \mathrm{O} 2, \mathrm{CO} 2, \mathrm{CH} 4, \mathrm{H} 2 \mathrm{~S})$, 11. signal recorder, 12. air flow controller)

Composition of each compost mixture in 7 chambers and initial parameters of materials used for composting are presented in tab. 1. The temperature inside the chamber was measured twice daily for the first 14 days and then from 15 day once a day using PT 100 sensors.

In the experiments carried out in 6 chambers, differentiated air flow was maintained and one chamber devoid of flow. Airflows were checked daily without allowing anaerobic conditions to occur.

Table 1. Initial parameters of materials used for composting

\begin{tabular}{|c|c|c|c|c|c|c|c|c|}
\hline \multicolumn{2}{|c|}{ Parameter/ chembers } & K0 & K1 & K2 & K3 & K4 & K5 & K6 \\
\hline \multicolumn{2}{|c|}{ Weight $[\mathrm{kg}]$} & 30.4 & 29.1 & 29.2 & 29.2 & 29.3 & 28.3 & 27.3 \\
\hline \multirow{2}{*}{$\begin{array}{l}\text { Dry } \\
\text { matter } \\
{[\%]}\end{array}$} & $\begin{array}{l}\text { Wastewater } \\
\text { sludge }\end{array}$ & 18 & 18 & 18 & 18 & 18 & 18 & 18 \\
\hline & Rape straw & 88 & 88 & 88 & 88 & 88 & 88 & 88 \\
\hline \multicolumn{2}{|c|}{ Volume $\left[\mathrm{dm}^{3}\right]$} & 97 & 106 & 114 & 111 & 111 & 125 & 129 \\
\hline \multicolumn{2}{|c|}{ Density $\left[\mathrm{kg} / \mathrm{m}^{3}\right]$} & 315 & 274 & 255 & 262 & 264 & 227 & 212 \\
\hline \multicolumn{2}{|c|}{ Flow rate $\left[\mathrm{dm}^{3} / \mathrm{min}\right]$} & 0 & 4 & 5 & 6 & 7 & 8 & 12 \\
\hline
\end{tabular}

\section{RESULTS}

The temperature at the start of the experiment was $20^{\circ} \mathrm{C}$ in each chamber. The rapid rise in temperature was noted only a few hours after closure of the chambers with the composted material. The transition from the mesophilic phase to the thermophilic phase (above $40^{\circ} \mathrm{C}$ ) occurred relatively quickly (within 3 days). The most intense thermophilic phase was in chamber $\mathrm{K} 1$ where it reached a maximum temperature of $68^{\circ} \mathrm{C}, \mathrm{K} 2$ and $\mathrm{K} 3-64.6^{\circ} \mathrm{C}$ and $\mathrm{K} 4-64.4^{\circ} \mathrm{C}$. The thermophilic phase did not occur in chamber $\mathrm{K} 0$ and reached a maximum value of $34.5^{\circ} \mathrm{C}$ (Fig. 2).

In the chambers with the lowest aeration $\mathrm{K} 1\left(4 \mathrm{dm}^{3} / \mathrm{min}\right)$, the temperature increase, in the thermophilic phase, was highest and reached a maximum value of $68.4^{\circ} \mathrm{C}$. In the $\mathrm{K} 5$ and K6 chambers, the thermophilic phase was not as intense and the maximum 
temperature was $57^{\circ} \mathrm{C}$. $\mathrm{K} 0$ while in the chamber, which was devoid of aeration the temperature course during the whole composting process was relatively similar.

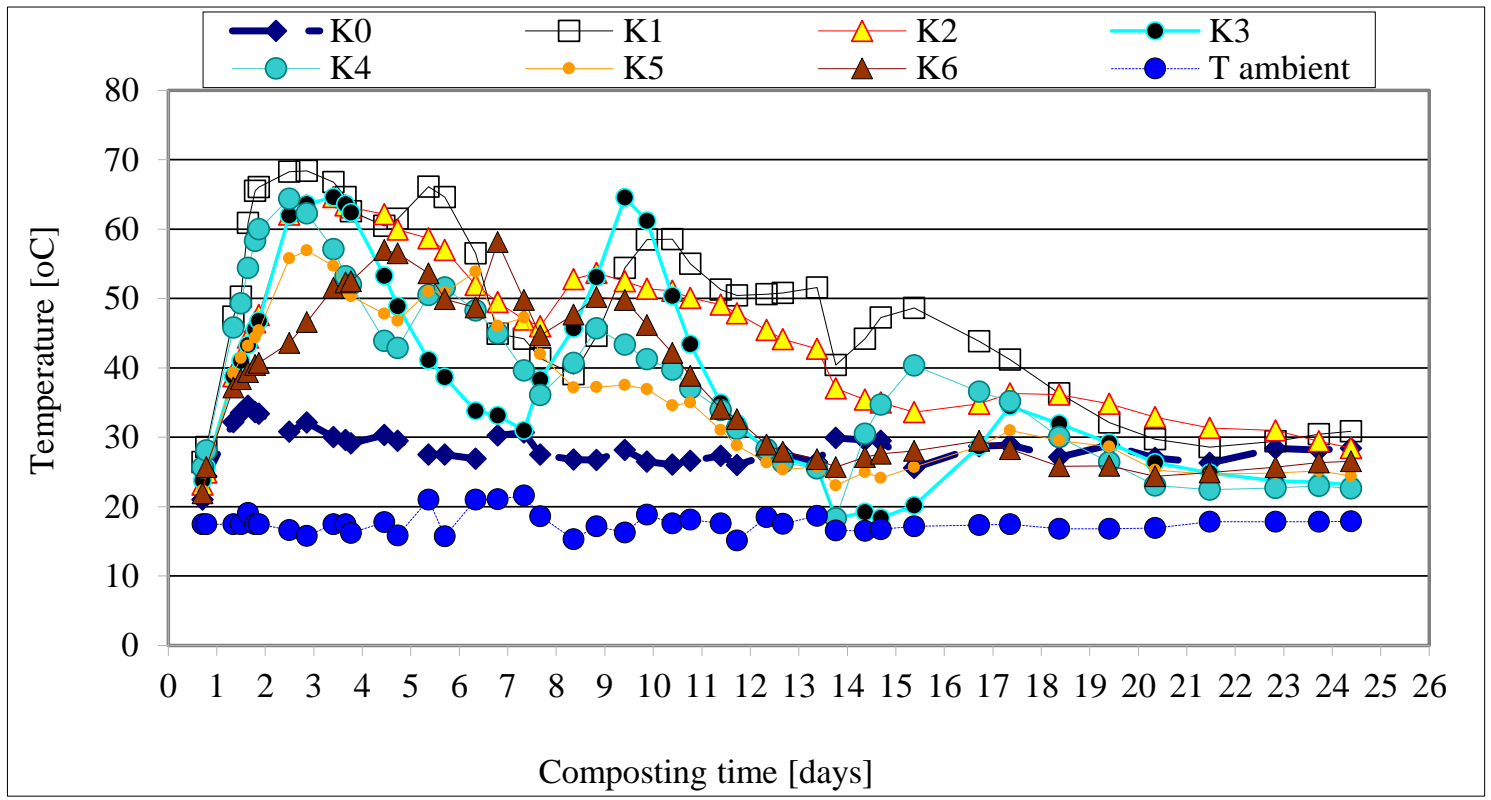

Figure 2. The course of temperature during the composting

Thus, the course of temperature changes was related to the aeration intensity of individual chambers. With less aeration, the thermophilic phase was much more intense. In the case of more air introduced, the processes were slower and longer. At the time of the temperature drop, aeration was performed on the sixth and thirteenth day of the experiment. After mixing, the temperature inside the chambers was rapidly reduced and the temperature increased again during the following days.

The process of the composting was dependent on temperature changes in the bioreactor. After 16 days, the temperature began to gradually decrease and about 21 days started the stabilization phase of the compost with a constant temperature of $30^{\circ} \mathrm{C}$. Stabilization of temperature was the decisive factor in the end of the experiment on day 25.

In the chambers with the lowest air flow $(\mathrm{K} 1, \mathrm{~K} 2)$, the cumulative temperature reached the highest values (Fig. 3). However, in the K3, K4, K5 and K6 chambers, where the aeration was higher, the cumulative temperature in the composted material was lower. This was due to the fact that excess air caused faster cooling of the material. During the experiment, changes in the weight and dry matter of the composted mixture were also investigated, and the results of weight reduction and dry matter content (in \%) are shown in Figure 3. In each of the chambers the final mass was reduced to the initial mass. The largest decrease in weight was recorded in K6 chamber from which it lost $15.67 \mathrm{~kg}(57.3 \%)$, then in $\mathrm{K} 4-16.41 \mathrm{~kg}(55.9 \%), \mathrm{K} 5-15.29 \mathrm{~kg}(53.9 \%), \mathrm{K} 2-14.33 \mathrm{~kg}$ (49\%), K3-14.21 (48.6\%), K1- $13.86(47.6 \%)$. The smallest weight loss of $4.46 \mathrm{~kg}$ $(14.8 \%)$ was noticed in the K0 chamber. K0 was deprived of aeration, which led to the occurrence of anaerobic conditions, so the mass decrease was the smallest. 


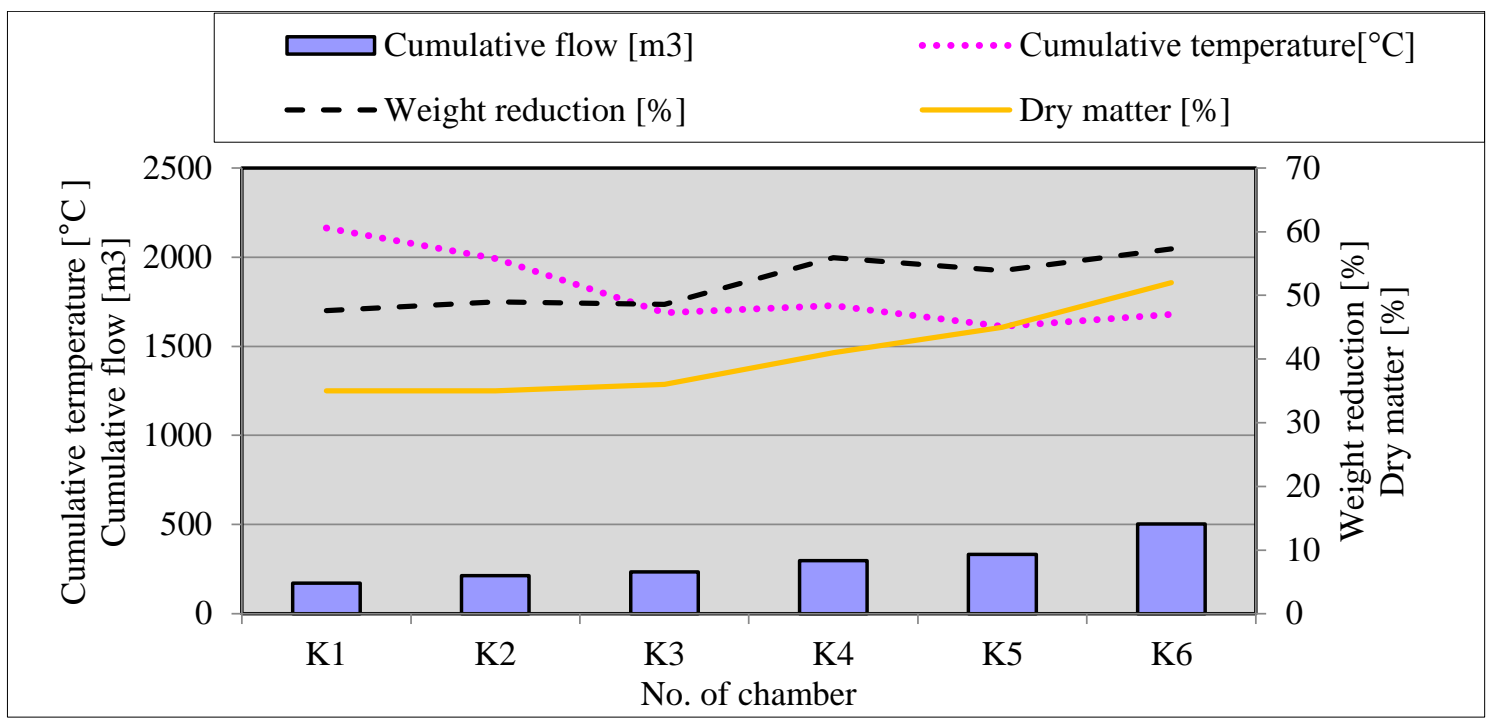

Figure 3. Relationship between cumulative temperature and air flow

\section{CONCLUSION}

In this study, a significant decrease in the weight of composted sewage sludge mixtures was observed in the range of $14.8-57.3 \%$. This proves the correct course of the process, as a number of authors state that intense thermophilic composting leads to a significant decrease in the mass of the material to be processed as a result of evaporation of water and $\mathrm{CO}_{2}$ emissions (Iranzo et al. 2004, Dach et al. 2007). These processes are associated with a very violent thermophilic phase, i.e. temperature increase to about $60^{\circ} \mathrm{C}$ for at least a few days.

The appropriate aerating of the compost mixture is one of the most important aspect during operation, which enables proper biomass conversion. From the energy point of view, the best aeration had a capacity of $4 \mathrm{dm}^{3} / \mathrm{min}$. But in these studies, it has been shown that even up to three times higher aeration intensity, relative to the most favorable energetically, allowed to obtain thermophilic conditions in the compost mixture. Moreover, it should be taken into account that weight reduction and dry matter increase positively correlated with increasing aeration intensity but negative with cumulative temperature, which is of particular importance when transporting the finished mixture.

\section{REFERENCES}

Bauza-Kaszewska J., Paluszak Z., Skowron K. (2010). Wpływ kompostowania osadów ściekowych na liczebność wybranych grup drobnoustrojów autochtonicznych. Water-Environment-Rural Areas. Instytut Technologiczno-Przyrodniczy w Falentach, 10/2(30), 19-27.

Berggren I., Albihn A., Johansson M. (2004). The effect of the temperature on the survival of pathogenic bacteria and Ascaris suum in stored sewage sludge. Sustainable organic waste management for environmental protection and food safety. Scien. paper RAMIRAN conference, Murcia, Spain, Vol 2. 6-9.

Białobrzewski I., Mikš-Krajnik M., Dach J., Markowski M., Czekała W., Głuchowska K. (2015). Model of the sewage sludge-straw composting process integrating different heat generation capacities of mesophilic and thermophilic microorganisms. Waste Management Volume 43, 72-83.

Czekała W., Dach J., Ludwiczak A., Przybylak A., Boniecki P., Koszela K., Zaborowicz M., Przybył K., Wojcieszak D., Witaszek K. (2015). The use of image analysis to investigate C:N ratio in the mixture of chicken manure and straw. Proc. SPIE. 9631, Seventh Intern. Conf. on Digital Image Proc. (July 06, 2015). 
Czekała W., Malińska K., Cáceres R., Janczak D., Dach J., Lewicki A. (2016). Co-composting of poultry manure mixtures amended with biochar - The effect of biochar on temperature and C-CO2 emission. Bioresource Technology 200, 921-927.

Dach J., Niżewski P., Jędruś A., Boniecki, P. (2007). Badania wpływu aeracji na dynamikę procesu kompostowania osadów ściekowych w bioreaktorze. J. of Research and App. in Agric. Eng. 52(1), 68-72.

Duan B., Zhang W., Zheng H., Wu C., Zhang Q., Bu Y. (2017). Disposal situation of sewage sludge from municipal wastewater treatment plants (wwtps) and assessment of the ecological risk of heavy metals for its land use in Shanxi. Int J Environ Res Public Health 14(7).

Eurostat (2017). Sewage sludge production and disposal. Last update: 15/09/17

Grau F., Drechsel N., Haering V., Trautz D., Weerakkody W.J.S.K., Drechsel P., Marschner B., Dissanayake D.M.P.S., Sinnathamby V. (2017). Impact of fecal sludge and municipal solid waste cocompost on crop growth of Raphanus Sativus L. and Capsicum Anuum L. under stress conditions. Resources 6 (3), 26.

Iranzo M., Canizares J.V., Roca-Perez L., Sainz-Pardo I., Mormeneo S., Boluda, R. (2004.). Characteristics of rice straw and sewage sludge as composting materials in Valencia (Spain). Biores. Techn. 95, 107-112.

Jezierska-Tyś S., Frąc M., Fidecki M. (2004). Wpływ nawożenia osadem ściekowym pochodzącym z mleczarni na przemiany azotu w glebie brunatnej. Annales UMCS. Sec. E., 59 (3) 1167-1173.

Kacprzak M., Neczaj E., Fijałkowski K., Grobelak A., Grosser A. (2017). Sewage sludge disposal strategies for sustainable development. Environmental Research 156, 39-46.

Kosicka D., Mazurkiewicz J., Mazur R., Wolna-Maruwka A. (2016). Kompostowanie osadów ściekowych komunalnych i przydomowych. Technologia Wody 46, 56-62.

Kosicka D., Wolna-Maruwka A., Mazurkiewicz J. (2015) Zagrożenia związane z występowaniem organizmów chorobotwórczych w osadach ściekowych oraz sposoby ich redukcji. Archives of Waste Management and Environmental Protection, 17 (4), 127-138.

Malamis D., Moustakas K., Haralambous K.J. (2016). Evaluating in-vessel composting in treating sewage sludge and agricultural waste by examining and determining the kinetic reactions of the process. Clean Techn Environ Policy 18 (8), 2493-2502.

Mroczek-Krzyzelewska E., Konieczny P., Lewicki A., Waśkiewicz, A., Janczak, D. (2017). Changes in acrylamide monomer content during composting of dairy processing sludge. Applied ecology and environmental research, 15(3), 39-50

Starzyk J., Czekała W. (2014). The Influence of Admixtures Accelerating the Pine Bark Composting Process on Variation in the Bacteriological State of Composts. Archives of environ. prot., 40/4, 125-135.

Ucaroglu S., Alkan U. (2016).Composting of wastewater treatment sludge with different bulking agents. $J$ Air Waste Manag Assoc. 66(3), 288-95.

Szwedziak K. (2006). Charakterystyka osadów ściekowych i rolnicze wykorzystanie. Inż. Rol.. 4, 297 302. 